\title{
Rancang Bangun Monitoring Daya Listrik untuk Aplikasi Sistem Tenaga Surya Berteknologi Smart Grid pada Skala Rumah Tinggal
}

\author{
Mukhamad Angga Gumilang \\ Jurusan Teknologi Informasi \\ Politeknik Negeri Jember \\ Jember, Indonesia \\ angga.gumilang@polije.ac.id
}

\author{
Hariyono Rakhmad \\ Jurusan Teknologi Informasi \\ Politeknik Negeri Jember \\ Jember, Indonesia \\ hariyono_r@polije.ac.id
}

\begin{abstract}
Utilization of solar cells can be used as a source of residential energy as a backup power source other than relying on supplies from PLN. In previous studies have not developed a system that monitors the power obtained from the utilization of solar cells. As a power monitoring tool a microcontroller and Internet-based (IOT) device is needed to provide information on the availability of backup power in the installation of solar power plants in homes. In this research, a PLTS design that is equipped with an IOT-based power monitoring system uses Arduino Uno and Thinkspeak. The results of the design can be applied to real conditions for the installation of solar power plants for residential homes. (Abstract)
\end{abstract}

Keywords - Internet of Things; Design of Solar Power Plants; Residential home ; Solar Cells; Power Monitoring System; Hybrid System; Smart Grid.

\begin{abstract}
Abstrak - Pemanfaatan sel surya dapat digunakan sebagai sumber energi rumah tinggal sebagai sumber daya cadangan selain bergantung pada pasokan dari PLN. Penelitianpenelitian yang ada belum banyak mengembangkan suatu sistem yang memonitoring daya yang didapatkan dari pemanfaatan sel surya tersebut. Sebagai alat monitoring daya diperlukan perangkat mikrokontroller dan berbasis Internet of Things (IOT) yang berguna memberikan informasi ketersediaan daya cadangan dalam pemasangan Pembangkit Listrik Tenaga Surya di rumah tinggal. Pada penelitian ini dipaparkan suatu rancang bangun Sistem Tenaga Surya (STS) berskala rumah tinggal menggunakan teknologi Smart Grid atau STS Hybrid yang dilengkapi sistem monitoring daya berbasis IOT menggunakan Arduino Uno dan Thinkspeak. Hasil rancangan dapat diaplikasikan pada kondisi nyata untuk instalasi PLTS untuk rumah tinggal. (Abstrak)
\end{abstract}

Keywords - Internet of Things; Solar Power Generation; Design; Residential home; Solar Cells; Power Monitoring System; Hybrid System; Smart Grid.

\section{PENDAHULUAN}

Energi merupakan salah satu kebutuhan utama rumah tangga. Di Indonesia sumber daya energi surya menjadi sangat potensial karena secara georgrafis mempunyai iklim tropis dan berada di garis khatulistiwa. Beberapa studi tentang penggunaan photovoltaic untuk kebutuhan rumah tangga mulai dilakukan pada tahun 2009 di Indonesia, namun masih sebatas menjadi daya cadangan dalam aplikasi
Pembangkit Listrik Tenaga Surya (PLTS) [1]. Kemudian peneliti lainnya mencoba melakukan studi kelayakan dengan hasil PLTS masih memerlukan biaya inventasi yang mahal untuk jangka pendek dan hanya mampu menyediakan listrik untuk setengah hari dari hasil penyerapan sinar matahari satu hari penuh [2].

Penelitian lanjutan dilakukan untuk meningkatkan efisiensi daya yang dihasilkan untuk kebutuhan rumah tangga. Efisiensi salah satunya dilakukan dengan cara memanfaatkan perangkat lunak dalam perencanaan kebutuhan untuk komplek perumahan [3], selain itu efisiensi juga dilakukan dengan menggunakan sel surya jenis monokristal (mono-cristallyne) [4]. Namun optimalisasi penggunaan energi listrik tenaga surya untuk rumah tangga tetap bergantung pada intensitas penyinaran matahari. Penelitian lain juga melakukan penyesuaian sudut panel surya untuk mendapatkan intensitas penyinaran yang optimum [7].

STS dengan teknologi Smart Grid atau STS Hybrid adalah di mana sumber listrik yang dihasilkan oleh Solar Cell dapat digabungkan dengan sumber listrik dari PLN. Cara kerjanya adalah secara bergantian di mana kedua sistem ini akan saling membackup ketika terjadi kekurangan daya listrik atau pemadaman. Dalam sistem ini, yang menjadi sumber energi utama adalah dari Panel Surya yang dikonversikan dan disimpan ke baterai, dan ketika pemakaian daya listriknya melebihi dari kapasitas baterainya, maka secara otomatis listrik dari PLN akan akan menggantikannya.

Usaha efisiensi yang dikemukakan pada penelitian sebelumnya masih belum memanfaatkan perangkat Internet of Things (IoT) dalam aplikasi penggunaan PLTS untuk kebutuhan rumah tangga. Padahal perangkat IoT secara sederhana dapat digunakan untuk memantau daya yang dihasilkan dan ketersediaannya untuk pemakaian listrik keburuhan rumah tangga. Aplikasi IoT untuk monitoring daya saat ini digunakan untuk memonitoring pemakaian energi secara umum [5], belum diterapkan untuk usaha efisiensi pemakaian energi yang dihasilkan dari aplikasi PLTS. Padahal IoT juga dapat dimanfaatkan tidak hanya sebagai sistem monitoring, melainkan sebagai sistem control berbagai perangkat elektronika [6].

Pada penelitian ini akan dipaparkan suatu rancang bangun sederhana pada STS Hybrid untuk kebutuhan rumah tangga dengan dilengkapi sistem monitoring daya. 
Penggunaan sistem monitoring daya diharapkan mampu memberikan informasi ketersediaan daya yang dihasilkan dari instalasi STS Hybrid tersebut dan menjadi acuan untuk usaha efisiensi penggunaan STS dengan menggunakan teknologi IoT. Hasil rancangan dapat diaplikasikan untuk kondisi nyata instalasi STS hybrid untuk rumah tinggal.

\section{PEMANFAATAN PEMBANGKIT LISTRIK TENAGA SURYA UNTUK RUMAH TINGGAL}

Penelitian yang mengkaji tentang penggunaan PLTS untuk kebutuhan rumah tangga sudah banyak dilakukan. Secara umum penelitian sebelumnya memaparkan berbagai rancangan PLTS yang cocok digunakan untuk kebutuhan rumah tangga. Hasil rancangan dan daya yang dihasilkan dalam penelitian pendahulu juga beragam dapat dilihat pada Tabel I.

TABle I. Hasil Penelitian tentang PEngGunaAn PLTS

\begin{tabular}{|c|c|c|c|}
\hline \multirow{2}{*}{ Variabel } & \multicolumn{3}{|c|}{ Penelitian } \\
\hline & [2] & [8] & {$[10]$} \\
\hline Tahun & 2009 & 2014 & 2017 \\
\hline $\begin{array}{l}\text { Rerata } \\
\text { Energi } \\
\text { yang } \\
\text { dihasilkan }\end{array}$ & 476,7 Watt/hour & 1.027 Watt/hour & 4070 Watt/hour \\
\hline $\begin{array}{l}\text { Jumlah } \\
\text { Panel Surya } \\
\text { yang } \\
\text { digunakan } \\
\end{array}$ & 2 buah & 2 buah & 5 buah \\
\hline $\begin{array}{l}\text { Spesifikasi } \\
\text { Teknis } \\
\text { yang } \\
\text { dibutuhkan }\end{array}$ & $\begin{array}{l}\text { - Inverter } 150 \\
\text { Watt } \\
\text { - Accumulator } \\
100 \mathrm{Ah}\end{array}$ & $\begin{array}{l}\text { - Inverter } 500 \\
\text { Watt } \\
\text { - Accumulator } \\
100 \mathrm{Ah}\end{array}$ & $\begin{array}{l}\text { - Inverter } 1500 \\
\text { Watt } \\
\text { - Batteray } 230 \\
\text { Ah }\end{array}$ \\
\hline $\begin{array}{l}\text { Proyeksi } \\
\text { penggunaan } \\
\text { energi }\end{array}$ & $450 \mathrm{VA}$ & $1300 \mathrm{VA}$ & $1300 \mathrm{VA}$ \\
\hline $\begin{array}{l}\text { Penggunaa } \\
\text { n PLTS }\end{array}$ & $\begin{array}{c}2 \text { lampu } \\
\text { Penerangan }\end{array}$ & $\begin{array}{l}4 \text { buah lampu } \\
\text { penerangan }\end{array}$ & Rumah tinggal \\
\hline
\end{tabular}

Tabel 1. Mengemukakan tiga contoh hasil penelitian yang mengemukanan rancangan sekaligus hasil uji PLTS yang diproyeksikan untuk penggunaan rumah tangga. Rata-rata energi yang dihasilkan juga beragam walaupun jumlah dan spesifikasi panel surya yang digunakan sama, hal ini dipengaruhi beberapa faktor antara lain: a) ambient air temperature: yaitu suhu panel surya bekerja, b) radiasi matahari, c) kecepatan angin bertiup, d) keadaan atmosfir bumi, e) orientasi panel atau larik sel surya, f) posisi letak sel surya terhadap matahari [8].

Dari segi ekonomis penerapan solar cell masih mahal untuk diterapkan jika dilihat dari biaya per $\mathrm{KwH}$ antara panel surya dan PT PLN bisa jadi dua kali lipat [2], namun keuntungan ekonomis penggunaan PLTS baru akan terlihat untuk pemakaian untuk jangka panjang, sebuah studi mensimulasikan untuk penggunaan PLTS rumah tangga per harinya hanya sebesar Rp. 31,884 untuk jangka pemakaian selama 25 tahun [9]. Biaya investasi untuk pembelian dan pemasangan PLTS juga sangat beragam, pada penelitian [9] dikemukakan biaya invetasi dan operasional masih berkisar ratusan juta. Sehingga diperlukan rancang bangun yang lowcost untuk pemakaian rumah tangga yang menengah untuk 900VA.
Pada penggunaan PLTS untuk jumlah rumah yang lebih banyak, langkah-langkah perancangan yang perlu dilakukan adalah [11]:

1) Menentukan Arus Beban Total dalam Ampere-Jam (Ah)

2) Rugi-rugi dan Faktor Keamanan Sistem

3) Menentukan jam Matahari Ekivalen (Equivalent Sun Hours, ESH) terburuk

4) Menentukan Kebutuhan Arus Total Panel Surya

5) Menentukan Susunan Modul Optimum untuk Panel Surya

6) Menentukan Kapasitas Baterai untuk Waktu Cadangan Yang Dianjurkan Umumnya

\section{SISTEM MONITORING DAYA}

Penelitian tentang pengembangan sistem monitoring daya listrik berbasis IoT mulai dikembangkan untuk penerapan monitoring pemakaian energi secara umum di Indonesia mulai tahun 2017. Salah satu contoh penelitian menghasilkan alat pemakaian energi listrik berbasis Android menggunakan modul PZEM-004T [12]. Dalam penelitian tersebut dihasilkan sistem yang dapat mengukur dan menampilkan arus, daya tegangan serta akumulasi energi secara real-time dengan error rate sebesar $10 \%$ [12].

Peneliti kedua tentang perancangan sistem monitoring daya juga mengembangkan sistem kendali dan monitoring daya berbasis Bluetooth [13], yang didapatkan alat control daya elektronika semu dengan hasil hasil pengukuran daya yang tidak jauh berbeda dengan multi-meter. Pada peneliti [13] digunakan sensor arus ACS712 5A, Sensor tegangan ZMPT101B, Mikrokontroler Arduino nano, Modul Bluetooth HC-05, Relay 4 chanel, papan PCB dan LCD $16 \times 2$.

Peneliti selanjutnya [14] juga mengusulkan satu Sistem Kontrol-Monitoring Daya Perangkat Elektronika dengan menggunakan IoT. Sistem dirancang menggunakan sensor arus ACS712 dan mikrokontroler Arduino Mega 2560 yang difungsikan untuk mengolah data parameter arus yang dibutuhkan untuk mendapatkan nilai konsumsi daya listrik [14]. Kemudian nilai tersebut dimasukkan ke database MySql melalui modul Ethernet Shield, serta dapat ditampilkan pada aplikasi Android. Aplikasi ini dibuat dengan menggunakan bahasa pemrograman php sebagai interface utama dan MySql sebagai pengolah datanya yang kemudian dikonversi menjadi aplikasi Android. Pengujian dilakukan satu per satu mulai dari sensor, mikrokontroler, komunikasi data, hingga aplikasi Android. Hasilnya menunjukkan bahwa sistem dapat bekerja dengan baik walaupun masih terdapat error pengukuran parameter [14].

Implementasi ketiga sistem monitoring daya yang dilakukan [12], [13], dan [14] belum ada yang diaplikasikan untuk monitoring daya di PLTS. Pada penelitian [12] penerapannya untuk lampu penerangan, peneliti [13] masih menerapkan sistem monitoring daya untuk alat elektronika semu dan percobaan [14] belum diimplementasikan pada rangkaian listrik yang nyata untuk rumah tangga. Untuk itu perlu dilakukan perancangan sistem monitoring daya yang spesifik untuk penggunaan PLTS untuk kebutuhan rumah 
tangga. Tujuan dari penerapan sistem monitoring daya untuk PLTS adalah sebagai langkah awal untuk efisiensi penggunaan daya.

\section{METODE PENELITIAN}

\section{A. Spesifikasi Teknis}

Dalam pengembangan STS hybrid dan sistem monitoring dayanya diperlukan beberapa alat dan bahan yang dapat dilihat pada Tabel II. Pada penelitian ini digunakan rancangan untuk kebutuhan rumah tangga 900VA. Dengan total estimasi penggunaan daya maksimal perhari 1500 Watt/hari, dengan kebutuhan paparan sinar matahari per hari $10 \mathrm{jam}$.

TABLE II. SPESIFIKASI TEKNIK UNTUK PLTS DAN SISTEM MONITORING DAYA

\begin{tabular}{|c|c|c|}
\hline Komponen & Spesifikasi & Keterangan \\
\hline $\begin{array}{l}\text { PV Module Panel } \\
\text { Surya }\end{array}$ & PV Modul Surya 100WP & $3 \mathrm{pcs}$ \\
\hline $\begin{array}{c}\text { Solar Charge } \\
\text { Controller }\end{array}$ & $30 \mathrm{~A} / 12$ Volt -24 volt & $1 \mathrm{pcs}$ \\
\hline Inverter & $\begin{array}{c}\text { Inverter DC } 23 \mathrm{~V} \text { to AC } 220 \mathrm{~V} \\
\text { / } 500 \mathrm{~W} \text { Pure Sine Wave }\end{array}$ & 1 Unit \\
\hline $\begin{array}{c}\text { Battery VRLA } \\
\text { AGM }\end{array}$ & 120Ah $12 \mathrm{~V}$ & 1 Unit \\
\hline Panel Box & Plat Coating & 1 Unit \\
\hline Lampu LED & $\begin{array}{c}\text { 5W (Lampu Bulat LED DC } \\
12 \text { Volt) }\end{array}$ & $2 \mathrm{pcs}$ \\
\hline Kabel Lampu & Kabel Power untuk Lampu & $\begin{array}{l}8 \text { Meter per } \\
\text { Lampu }\end{array}$ \\
\hline Fitting Lampu & Fitting Lampu Standar & $4 \mathrm{pcs}$ \\
\hline Stop Kontak & Stopkontak 1 Lubang & $1 \mathrm{pcs}$ \\
\hline $\begin{array}{l}\text { USB phone } \\
\text { charge }\end{array}$ & 1 Port & $1 \mathrm{pcs}$ \\
\hline Accessories & Saklar, Soket Panel Surya & 1 Unit \\
\hline Mikrokontroller & Arduino Mega & 1 paket \\
\hline Sensor Arus & ACS 712 & 1 paket \\
\hline Ethernet Shield & W5100 & 1 paket \\
\hline Relay & SPDT 5 Volt DC & 1 paket \\
\hline Router & Andromax M2Y & 1 paket \\
\hline Smartphone & Oppo A9 2020 & 1 paket \\
\hline
\end{tabular}

\section{B. Perancangan Blok Diagram}

Dalam perancangan diagram blok adalah hasil penggabungan dari dua sistem, yang pertama merupakan STS dan yang kedua merupakan sistem monitoring daya berbasis IoT. Dalam perancangan STS hybrid ini terdapat beberapa komponen seperti solar panel yang dihubungkan ke dalam charge controller, hasil pengisian daya kemudian disimpan dalam battery yang dihubungkan ke inverter/DC Load untuk digunakan aplikasi penggunaan listrik untuk rumah tangga. Di dalam battery STS kemudian dihubungkan sensor arus ACS712 secara seri. Tujuannya agar arus yang mengalir dapat dideteksi sensor arus ACS712. Setelah arus listrik mengalir melalui sensor arus ACS712 maka arus listrik tersebut terbaca oleh sensor arus ACS712 yang kemudian akan mengeluarkan output tegangan $5 \mathrm{~V}$ ke mikrokontroler Arduino Mega 2560 melalui pin analog. Pada sistem ini juga dipasang relai secara seri sehingga beban listrik dapat dikendalikan melalui pin digital. Rangkaian dari sistem sensor dan beban ini dapat dilihat pada Gambar 1 .
Pada penelitian ini, variabel yang diukur dan dipantau adalah daya listrik. Sensor arus digunakan karena arus listrik memiliki hubungan dengan daya listrik seperti pada persamaan (1).

$$
\mathrm{P}=\mathrm{VI}
$$

dengan $\mathrm{P}$ adalah daya (Watt), $\mathrm{V}$ adalah tegangan (Volt), dan I adalah arus (Ampere). Untuk mendapatkan nilai daya, maka data pembacaan sensor arus kemudian dikonversi pada bahasa pemrograman dan dikalikan dengan nilai tegangan AC sebesar $220 \mathrm{~V}$.

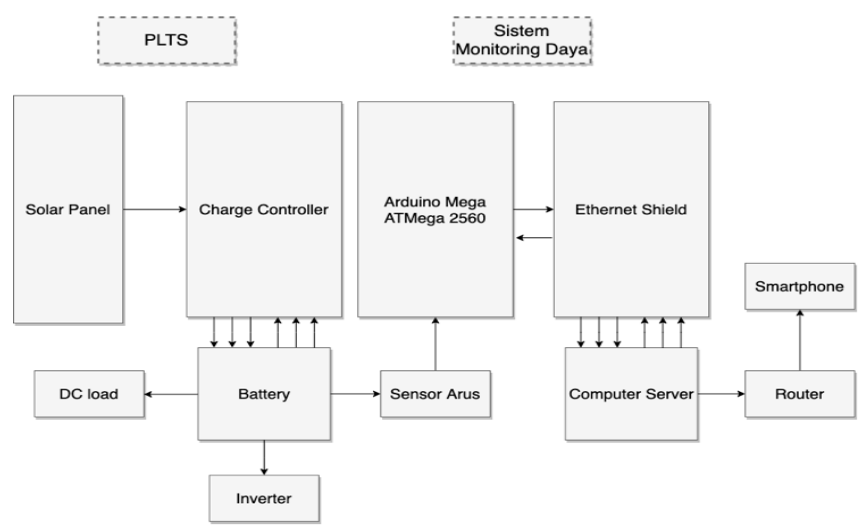

Gambar 1. Diagram Blok Perancangan Sistem

\section{Perancangan Perangkat Lunak}

Perancangan perangkat lunak dimulai dari membuat logika pemrograman dengan menggunakan IDE Arduino, bahasa yang digunakan adalah $\mathrm{C}$ agar mikrokontroller bisa bekerja sesuai rancangan. Selanjutnya web server dipersiapkan untuk menerima data dari perangkat mikrokontroller. Untuk pengembangan aplikasi Android digunakan Teknik web view, dimana yang diakses merupakan web dari versi tampile mobile.

Dalam perancangan program monitoring daya listrik, terdapat fungsi untuk menampilkan pemakaian daya yang didapat dari sensor. Kemudian terdapat percabangan/opsi untuk menampilkan data pemakaian. Setelah itu akan didapat opsi untuk memfilter rentang waktu. Jika inputan rentang waktu tersebut benar. Maka akan ditampilkan data informasi pemakaian berdasarkan inputan parameter tersebut. Diagram alur monitoring daya dapat dilihat pada Gambar 2.

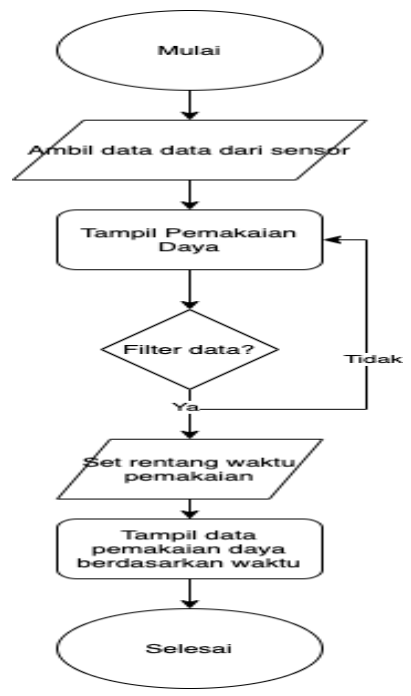

Gambar 2. Diagram Alur Sistem Monitoring Daya 
Dalam perancangan perangkat lunak, juga dirancang sistem database dimana terdapat 1 tabel yaitu tabel sensor_logs yang berfungsi sebagai storage dari data pemakaian daya listrik. Adapun struktur tabelnya dapat dilihat pada Tabel III. Kemudian dirancang antarmuka yang berfungsi sebagai panduan dan tolak ukur pembuatan tampilan aplikasi yang telah terinstregasi dengan alat yang nantinya akan digunakan oleh pengguna aplikasi. Desain tampilan antarmuka Android dapat dilihat pada Gambar 3.

TABLE III. Perancangan TABel Database Sistem

\begin{tabular}{|c|}
\hline LOGS \\
\hline ID: INT (10) \\
\hline DATE: TIMESTAMP \\
\hline WATTA: INT (10) \\
\hline WATTB: INT(10) \\
\hline TOTAL_WATT: INT(10) \\
\hline
\end{tabular}

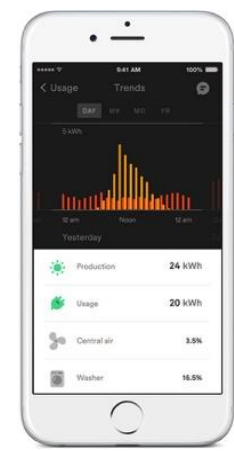

Gambar 3. Diagram Antarmuka Aplikasi Android

Dalam perancangan jaringan, dibutuhkan setidaknya 1 buah router dan 1 buah kabel RJ-45 untuk saling menghubungkan antara Arduino, komputer, dan smartphone Android. Kabel RJ-45 berfungsi sebagai media transmisi data yang menggunakan kabel yang akan mengirimkan data antara mikrokontroler Arduino dan komputer. Router berfungsi sebagai media transmisi data yang bersifat nirkabel yang akan mengirimkan data dari komputer ke smartphone Android. Untuk lebih jelasnya, diagram blok dari sistem jaringan yang dirancang dapat dilihat pada Gambar 4.

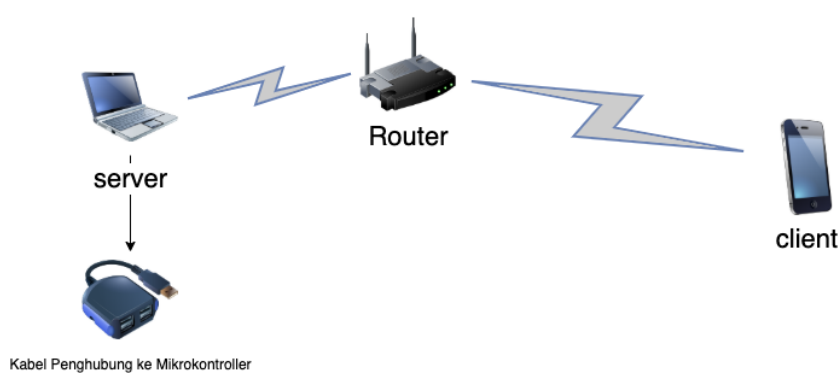

Gambar 4. Diagram Sistem jaringan

\section{HASIL DAN PEMBAHASAN}

\section{A. Pengujian Sistem Tenaga Surya Teknologi Hybrid}

Pengujian daya yang didapat dari spesifikasi teknis STS Hybrid dilakukan saat paparan sinar matahari terik selama 10 jam, dengan maksimal penggunaan daya yang dihasilkan maksimal 1500 Watt. Besaran rentang daya yang dihasilkan STS hybrid beragam setiap harinya, dari rentangan 900 s.d
1500 Watt. Dalam pengujian STS hybrid yang dilakukan dalam penelitian ini, ada beberapa perangkat listrik sebagai konsumen daya yang dihubungkan sebagai asumsi penggunaan listrik rumah tangga 900VA diantaranya: lampu LED, mesin cuci, tv dan pompa air. Untuk hasil pengujian daya yang dihasilkan dapat dilihat pada Tabel IV.

TABLE IV. HASIL PENGUJIAN DAYA YANG DIHASILKAN PLTS UNTUK ALOKASI MASING-MASING PERANGKAT

\begin{tabular}{|c|c|c|c|c|}
\hline Perangkat & Jumlah & $\begin{array}{c}\text { Daya } \\
\text { (Watt) }\end{array}$ & $\begin{array}{c}\text { Hasil } \\
\text { Pengujian } \\
\text { (Jam) }\end{array}$ & $\begin{array}{c}\text { Kebutuhan } \\
\text { Daya } \\
\text { (Watt) }\end{array}$ \\
\hline Lampu LED & 2 & 5 & 12 & 120 \\
\hline Lampu LED & 2 & 7 & 12 & 168 \\
\hline Mesin Cuci & 1 & 100 & 3 & 300 \\
\hline TV & 1 & 75 & 4 & 300 \\
\hline Pompa Air & 1 & 150 & 2 & 300 \\
\hline & & & Total Daya & 1.188 \\
\hline
\end{tabular}

\section{B. Pengujian Sistem Monitoring Daya}

Pengujian sistem monitoring daya ini dilakukan untuk mengetahui keakuratan sistem monitoring daya dalam menghitung arus listrik AC yang dihasilkan STS hybrid dan membandingkannya dengan multimeter yyang merupakan pengukur standar untuk arus listrik AC pada battery. Dalam pengujian sistem monitoring daya terdapat nilai error yang berfungsi sebagai informasi tingkat keakuratan sistem monitoring daya. Adapun rumus untuk menghitung nilai error tersebut adalah seperti persamaan (2) berikut.

$$
E(\%)=\frac{a-k}{a} \times 100
$$

dengan adalah nilai error dalam persen, adalah nilai arus dari alat ukur, dan nilai arus dari sensor. dengan adalah nilai error dalam persen, adalah nilai arus dari alat ukur, dan nilai arus dari sensor. Hasil pengujian dari sensor arus dapat dilihat pada Gambar 5. Berdasarkan hasil pengujian, terdapat nilai rata-rata error pada pengukuran arus lampu sebesar $10,08 \%$.

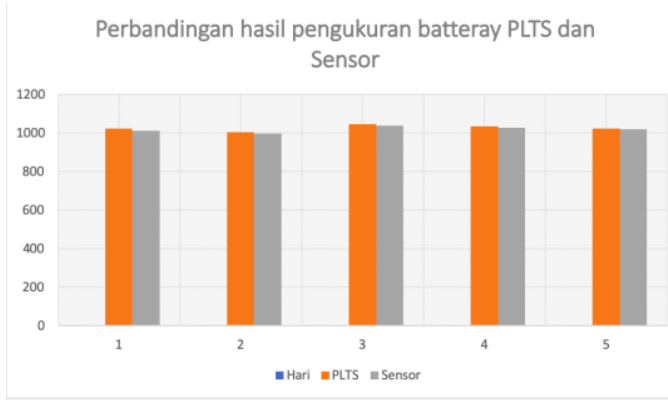

Gambar 4. Hasil Pengujian Sistem Monitoring Daya

\section{KESIMPULAN}

Aplikasi monitoring daya pada Sistem Tenaga Surya teknologi Hybrid telah dirancang dalam penelitian ini. PLTS yang dihasilkan mampu menghasilkan daya dalam rentang 900 Watt sampai dengan 1500 Watt. Sedangkan pada sistem monitoring daya dapat bekerja walaupun masih terdapat error dalam membaca daya yang dihasilkan pada baterai STS. Pada penelitian selanjutnya perlu dikembangkan sistem 
kontrol yang dapat bekerja otomatis ketika daya yang dikonsumsi dari STS hybrid melebihi batas yang ditentukan. Fitur ini akan menjadi usaha dalam efisiensi penggunaan STS hybrid dalam kebutuhan rumah tangga. Sistem monitoring berbasis Android juga dirancang dengan menggunakan komunikasi internet sehingga dapat mempermudah pengguna mendapatkan informasi yang dibutuhkan.

\section{REFERENSI}

[1] T. T. Gultom, "Pemanfaatan photovoltaic sebagai pembangkit listrik tenaga surya," pp. 33-42.

[2] T. Utomo, and B. T. Manfaat, "DAYA LISTRIK SKALA RUMAH TANGGA,” vol. III, no. 167, pp. 13-17, 2009.

[3] M. Syukri and K. Kunci, "Perencanaan Pembangkit Listrik Tenaga Surya ( PLTS ) Terpadu Menggunakan Software PVSYST Pada Komplek Perumahan di Banda Aceh,” vol. 9, no. 2, 2010.

[4] D. Dzulfikar and W. Broto, "OPTIMALISASI PEMANFAATAN ENERGI LISTRIK TENAGA SURYA Abstrak,” vol. V, pp. 73-76, 2016.

[5] F. Nur and S. Setiawidayat, "Alat Monitoring Pemakaian Energi Listrik Berbasis Android Menggunakan Modul PZEM-004T," vol. 01, no. 01, pp. 157-162, 2017.

[6] T. D. Hendrawati, Y. D. Wicaksono, and E. Andika, "Internet of Things: Sistem Kontrol-Monitoring Daya Perangkat Elektronika," vol. 3, no. 2, pp. 177-184, 2018.

[7] D. Dzulfikar and W. Broto, "OPTIMALISASI PEMANFAATAN ENERGI LISTRIK TENAGA SURYA” vol. V, pp. 73-76, 2016.

[8] As'ary, Hasim, et al., "Pemanfaatan solar cell dengan pln sebagai sumber energi listrik rumah tinggal," vol. 14, no. 01, pp. 33-39, 2014.
[9] S. Putra, et al, "Perencanaan Pembangkit Listrik Tenaga Surya Secara Mandiri Untuk Rumah Tinggal,” pp. 1-7, 2016.

[10] M. F. Hakim, "PERANCANGAN ROOFTOP OFF GRID SOLAR PANEL PADA RUMAH TINGGAL," vol. 8, no. 1, pp. 1-11, 2017.

[11] Bachtiar, Mochammad, "Prosedur perancangan sistem pembangkit listrik tenaga surya untuk perumahan (solar home system)." Jurnal SMARTek, Vol. 4, No. 3, Agustus 2006: 176 - 182

[12] F. Nur and S. Setiawidayat, "Alat Monitoring Pemakaian Energi Listrik Berbasis Android Menggunakan Modul PZEM-004T," vol. 01, no. 01, pp. 157-162, 2017.

[13] K. Nadliroh and E. M. Indrawati, "Rancang bangun kendali perangkat elektronik dan monitoring daya listrik berbasis bluetooth," vol. 1, no. 2, pp. 77-84, 2018.

[14] T. D. Hendrawati, Y. D. Wicaksono, and E. Andika, "Internet of Things: Sistem Kontrol-Monitoring Daya Perangkat Elektronika," vol. 3, no. 2, pp. 177-184, 2018 